\title{
Economic Factors Affecting Rice Price Fluctuation in North Sumatera
}

\author{
Mariana Eva Yanti ${ }^{1}$, Octasella Ainani As'ad ${ }^{2}$, Faiz Ahmad Sibuea \\ ${ }^{1}$ Agribusiness Master Departement, Faculty of Agriculture, Universitas Islam Sumatera Utara, Indonesia \\ ${ }^{2}$ Agribusiness Departement, Faculty of Economic Management, IPB, Indonesia
}

\begin{abstract}
The research approach method is a qualitative approach. The method of data collection is secondary data, secondary data needed is obtained from relevant agencies, namely from the Central Bureau of Statistics and the Department of Agriculture as well as other literature related to research. The analytical method used is descriptive analysis and analysis of Vector Auto Regression (VAR). The results showed that: 1) The dominant factors affecting rice prices in North Sumatra are 2, the first is $60 \%$ production because the higher the production of rice, the price of rice will decline and the lower the production, the price of rice will increase and the second factor is $38 \%$ inflation because if the price of rice continues to increase there will be inflation, but it is different from the fact that rice prices fluctuate due to the stability of rice prices. 2) Factors that affect rice prices in North Sumatra in the short term are significant, namely inflation and in the long term there are five significant factors, namely production (prod), harvest area (field), income (inc), consumption (cons)) and inflation (inf). 3) From Impulse Response Function Analysis, it can be seen that the factors that influence rice prices in North Sumatra can be seen as stability, namely the production variable (Prod) reaches stability in the 25th period, the penen variable (Field) reaches stability in the period 28, the consumption variable (Cons) reaches stability in the 25th period, the income (Inc) variable reaches stability in the 20 th period, the inflation variable reaches stability in the 27th period. namely inflation and in the long term there are five significant factors, namely production (prod), harvest area (field), income (inc), consumption (cons) and inflation (inf).
\end{abstract}

\section{Keywords}

rice production and rice price; consumption; harvest area; inflation

\section{Introduction}

The island of Sumatra is one of the islands that has a high population in Indonesia, especially in the province of North Sumatra, so it requires food security for various existing commodities. Several time periods that occurred in the Province of North Sumatra indicate a scarcity of several commodities that can cause fluctuating price fluctuations. Therefore, the availability of various commodities is very important in maintaining price stability and macroeconomic stability in a region

The retail price of rice experiences price fluctuations, therefore the government must take a policy to stabilize the retail rice price so that consumers and producers do not experience significant losses. Price stability is a government policy which aims to protect rice producers and consumers. If producers are not profitable, it will reduce rice supply, indirectly it will affect the availability of rice for purchase and consumption by consumers. If the price of rice increases continuously due to limited rice availability, it could result in decreased food security in North Sumatra. 
The role of the agricultural sector given to the economic development of North Sumatra is very large, so the agricultural sector must continue to be developed by the government, but on the other hand the fact that the agricultural sector has decreased is very unfortunate (Lubis et al, 2020). According to Solow's theory there are a number of things being done to spur economic growth. Increasing the portion of savings will increase capital accumulation and accelerate economic growth. In addition, increasing investment is appropriate in the economy both in physical and non-physical forms. Encouraging technological progress can increase income per workforce so that the opportunity to innovate in the private sector will have a major influence on economic growth (Hasibuan ET AL, 2020).

According to Noer and Agus (2007), agricultural land area and production per hectare are influenced by changes in prices and production per hectare, also influenced by changes in planted area. The conclusion that resulted from his research was that the increase in rice production was the result of an increase in the number of planted areas. The high amount of rice imports can also be seen from the area of harvested land and yields per hectare in North Sumatra in get decreased agricultural harvested area from the previous year resulting in a decrease in rice production in 2014. According to Sawastika et al (2000), one of the causes of fluctuating rice production national is the conversion of agricultural land to housing which continues and results in a decline in rice supply.

Based on microeconomic theory, changes in the price of a commodity are determined by the amount of demand and supply of the commodity. The relationship between the price of a commodity and the quantity demanded follows a basic economic hypothesis which states that the higher the price of a commodity, the lower the quantity of that commodity is demanded, assuming other variables are considered constant (ceteris paribus) and vice versa (Lia, 2010).

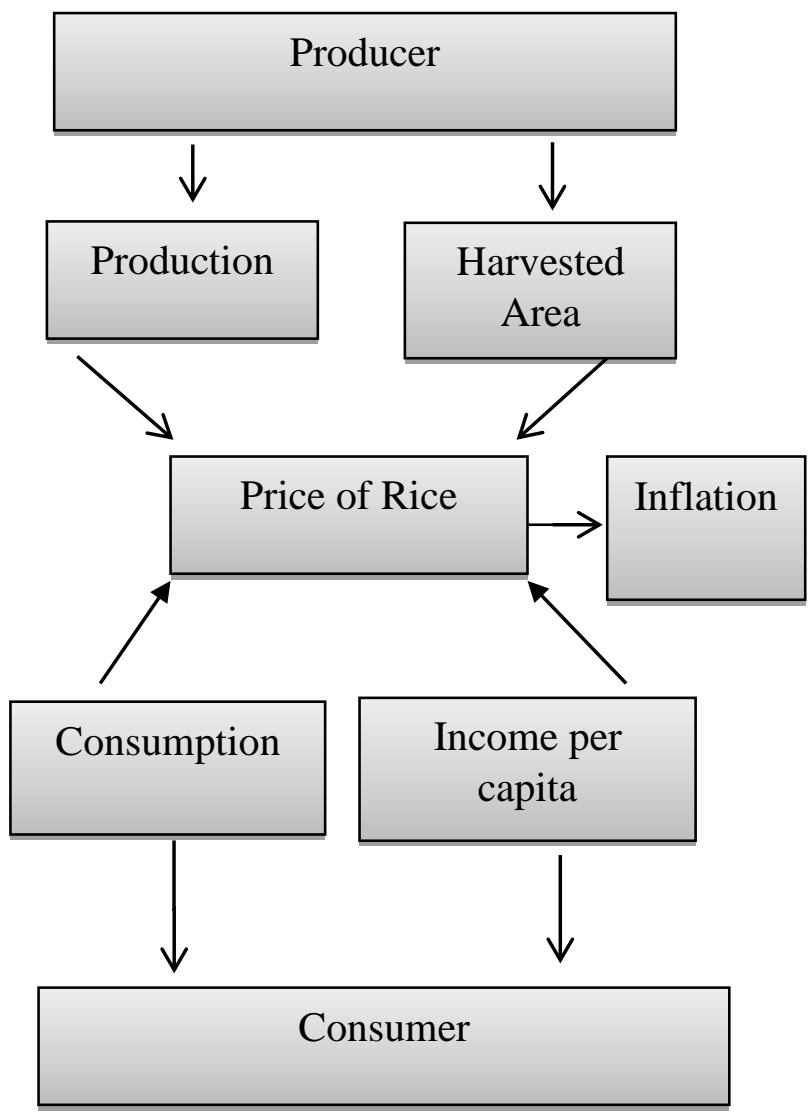


Based on the picture, changes in the price of a commodity are determined by the amount of demand and supply of the commodity. The relationship between the price of a commodity and the quantity demanded follows a basic economic hypothesis which states that the higher the price of a commodity, the lower the quantity of the commodity demanded, assuming other variables are considered constant (ceteris paribus). Meanwhile, the relationship between the price of a commodity and the quantity supplied follows a basic economic hypothesis which states that in general, the higher the price of a commodity, the greater the quantity of commodity and the quantity supplied follows a basic economic hypothesis which states that in general the higher the price of commodity, the greater of quantity commodity supplied by assuming other variable which are considered constant (ceteris paribus). The price of commodity is formed by the intersection between of demand and supply curve. So the quantity demanded is the same of the quantity of supply.

\section{Research Methods}

\subsection{Data and Data Collection Methods}

The data source in this research is secondary data. The secondary data required is obtained from related agencies, namely from the Central Statistics Agency and the Food Security Service and other literature related to the research. The secondary data required includes the condition of the research area, the amount of production, consumption, harvested area, per capita income and inflation as well as supporting institutions, namely data sources that are relevant to the research objectives in the form of documents and reports from existing relevant agencies in North Sumatra.

\subsection{Vector Auto Regression (VAR) Analysis Method}

Vector Auto Regression (VAR) analysis is used to project a system with time series variables and to analyze the dynamic impact of the disturbance factors contained in the variable system. Basically VAR analysis is the same as a simultaneous equation model, because in VAR analysis we consider several endogenous variables together in a model. The general VAR equation model can be written as follows (Enders,

2004) as follows:

$$
Y_{t-1}=+++\alpha_{11} \beta_{11 Y_{t}} \beta_{12 X_{1}} \beta_{13 X_{2}}
$$

The VAR model uses the variables Production, Harvested Area, Consumption, Income per capita and the price of rice and inflation, namely:

P.Rice

$$
\begin{aligned}
& \text { ++++++ } \\
& \alpha_{11} \beta_{11} \text { Prodt }_{t-1} \beta_{12} \text { Field }_{t-1} \beta_{13} \text { Cons }_{t-1} \beta_{14} \text { Inc }_{t-1} \beta_{15} \text { P.Inf } \text { In-1 }_{16} \beta_{16} \text { P. } \text { Rice }_{t-1}+ \\
& \in
\end{aligned}
$$

Prod

$$
\begin{aligned}
& ++++++ \\
& \alpha_{21} \beta_{21} \text { Field }_{t-1} \beta_{22} \text { Cons }_{t-1} \beta_{23} \operatorname{Inc}_{t-1} \beta_{24} \operatorname{Inf}_{t-1} \beta_{25} \text { P. Rice }{ }_{t-1} \beta_{26} \operatorname{Prod}_{t-1}+
\end{aligned}
$$

$\in$

Field

$$
\begin{aligned}
& ++++++ \\
& \alpha_{31} \beta_{11} \text { Cons }_{t-1} \beta_{32} \text { Prodt }_{t-1} \beta_{33} \text { Inc }_{t-1} \beta_{34} \text { Inf }_{t-1} \beta_{35} \text { P. Rice }_{t-1} \beta_{36} \text { Field }_{t-1}+ \\
& \quad \in
\end{aligned}
$$


Cons

$++++++$

$\alpha_{41} \beta_{41}$ Inc $_{t-1} \beta_{42}$ Prodt $_{t-1} \beta_{43}$ Field $_{t-1} \beta_{44}$ Inf $_{t-1} \beta_{45}$ P. Rice $_{t-1} \beta_{46}$ Cons $_{t-1}+$ $\in$

Inc

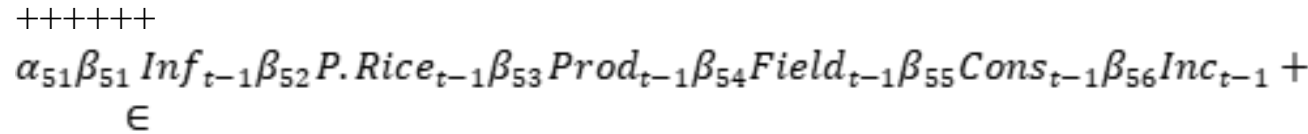

Inf

$+++++$

$\alpha_{61} \beta_{61}$ P. $_{\text {Rice }}+1 \beta_{62}$ Prod $_{t-1} \beta_{63}$ Field $_{t-1} \beta_{64}$ Cons $_{t-1} \beta_{55} \operatorname{Inc}_{t-1} \beta_{56} \operatorname{Inf}_{t-1}+$ $\in$

Information:

$\alpha=$ Constant

$\beta=$ Variable constant

$t-1=$ This year deducted 1

$\epsilon=$ Error

There are several stages in carrying out a VAR analysis, namely:

1. Data Stationarity Test

The first step to estimating the VAR model is the data stationarity test. The data stationarity test can be done using the unit root test in the model.

2. Determination of the Optimal Lag

Another important thing in estimating the VAR model is the determination of lag. The optimal lag is needed in order to capture the effect of each variable on the other variables in the VAR system.

3. VAR Model Stability Test

The next step is to test the stability of the VAR. The VAR stability test is done by calculating the roots of the polynomial function or known as the roots of characteristic polynomial.

4. Cointegration Test

The cointegration test aims to determine whether the variables are not stationary and are not cointegrated.

5. Vector Error Correction Model (VECM)

Engle and Granger (1987) in Widarjono (2013) state that time series data are often not stationary at the level or non-stationary level of data, but a linear combination of two or more non-stationary data becomes stationary. 


\section{Results and Discussion}

The stationarity test was carried out to ensure that the research variable did not have a unit root. The criteria used is Augmented Dickey-Fuller (ADF), with a confidence interval of $5 \%$.

Table 1. Stationarity test results at the level level

\begin{tabular}{lcrccl}
\hline \multicolumn{1}{c}{ Variable } & $\begin{array}{c}\text { ADF } \\
\text { statistics }\end{array}$ & \multicolumn{3}{c}{$\begin{array}{c}\text { MacKinnon critical } \\
\text { value }\end{array}$} & Information \\
\cline { 1 - 5 } & & $1 \%$ & $5 \%$ & $10 \%$ & \\
\hline Price & -1.358967 & -3.699871 & -2.976263 & -2.627420 & Not Stationary \\
Production & -1.379688 & -3.679322 & -2.967767 & -2.622989 & Not Stationary \\
Harvest area & -1.522041 & -3.679322 & -2.967767 & -2.622989 & Not Stationary \\
Consumption & -2.308563 & -3.769597 & -3.004861 & -2.642242 & Not Stationary \\
Income & -1.422639 & -3.679322 & -2.967767 & -2.622989 & Not Stationary \\
Inflation & -5.906736 & -3.679322 & -2.967767 & -2.622989 & Not Stationary \\
\hline
\end{tabular}

Table 2. Stationarity test results at the level first difference

\begin{tabular}{lrcccl}
\hline \multicolumn{1}{c}{ Variable } & ADF & \multicolumn{3}{c}{ MacKinnon critical value } & Information \\
\cline { 3 - 5 } & statistics & $1 \%$ & $5 \%$ & $10 \%$ & \\
\hline Price & -5.438807 & -3.699871 & -2.976263 & -2.627420 & Stationary \\
Production & -7.491681 & -3.689194 & -2.971853 & -2.625121 & Stationary \\
Harvest area & -4.973094 & -3.689194 & -2.971853 & -2.625121 & Stationary \\
Consumption & -5.976400 & -3.689194 & -2.971853 & -2.625121 & Stationary \\
Income & -5.800279 & -3.689194 & -2.971853 & -2.625121 & Stationary \\
Inflation & -5.042917 & -3.724070 & -2.986225 & -2.632604 & Stationary \\
\hline
\end{tabular}

\subsection{Determination of Optimal Lag}

In this study, based on the results of the optimal lag calculation suggested by all the criteria is the 2 nd lag, so that the optimal lag is chosen as the 2nd lag.

Table 3. Determination results lag optimal

\begin{tabular}{cccccl}
\hline Lag & LogL & LR & FPE & AIC & SC \\
\hline 0 & 50.9852 & NA & $1.44 \mathrm{e}-09$ & -3.332237 & $-3.044273 *$ \\
1 & 93,3508 & $62.7640 *$ & $9.66 \mathrm{e}-10$ & -3.803770 & -1.788024 \\
2 & 138.1235 & $7.89 \mathrm{e}-10 *$ & $-4.453593 *$ & & -0.710064
\end{tabular}

Remarks: * recommended optimal lag 
3.2 Vector Error Correction Model (VECM) Estimation

Table 4. VECM estimation results

Short-term

\begin{tabular}{ccc}
\hline Variable & Coefficient & T-statistics \\
\hline CointEq1 & -0.282907 & {$[-1.91120]$} \\
D (D Price (-1)) & -0.696602 & {$[-4.23238]$} \\
D (D Production (-1)) & 0.858273 & {$[0.70165]$} \\
D (D Harvested area (-1)) & -3.806207 & {$[-1.07435]$} \\
D (D Consumption (-1)) & 1.453928 & {$[0.52488]$} \\
D (D Income (-1)) & 0.010159 & {$[0.12831]$} \\
D (D Inflation $(-1))$ & 0.005049 & {$[0.92888]$} \\
C & 0.031958 & {$[0.47674]$} \\
\hline
\end{tabular}

\section{Long-term}

\begin{tabular}{ccc}
\hline Variable & Coefficient & T-statistics \\
\hline DHarga (-1) & 1,000000 & - \\
D Production (-1) & 7.664951 & {$[1.76264]^{*}$} \\
D Harvest area (-1) & -30.06845 & {$[-7.60917]^{*}$} \\
D Consumption (-1) & 20.14268 & {$[6.51096]^{*}$} \\
D revenue (-1) & 0.345491 & {$[3,44872]^{*}$} \\
Inflation (-1) & 0.039616 & {$[3,47437]^{*}$} \\
C & 0.106414 & - \\
\hline
\end{tabular}

Note: * significant at 5\% confidence interval

3.3 Impulse Response Function (IRF) Analysis

Response to Cholesky One S.D. Innovations

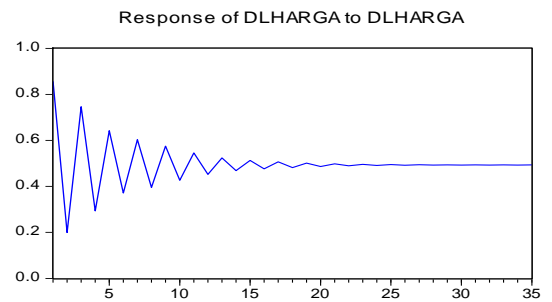

Response of DLCONS to DLHARGA
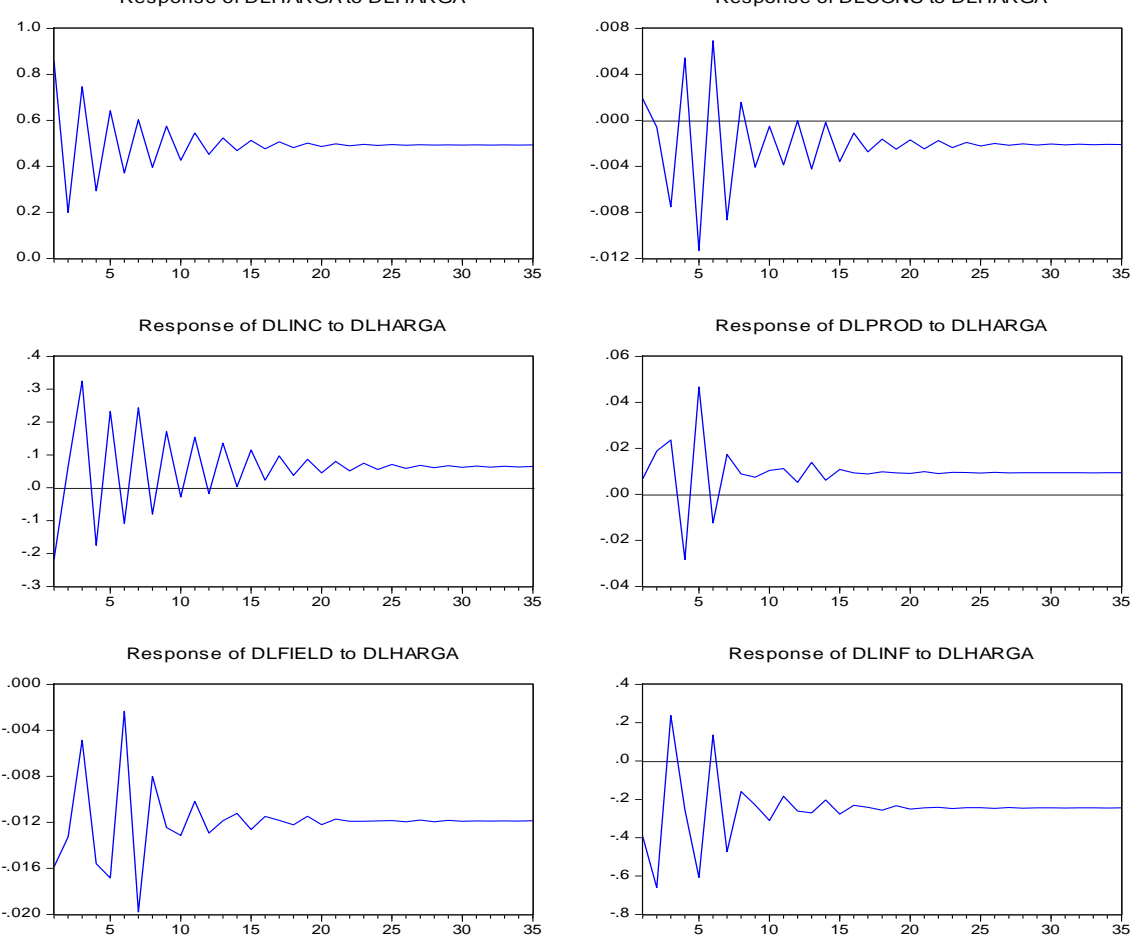
The analysis of the inflation response to price shocks of each food commodity is projected over the next 35 periods of the study period. In general, the results of the IRF analysis state that the price shocks of food commodities in the initial period have not been responded to by inflation in the long run approaching the point of stability. It show that the fluctuation of food commodities doesn't have a permanent impact

In addition, the response of rice prices previous rice prices in the first, second, third, fourth and fifth periods has fluctuated up to the sixth or 30-year period towards the inflection point (point to zero). The effect of rice prices on previous rice prices can be caused by the price of rice in the domestic market and the price of rice in the international market.It can be seen from the law of demand that if rice production increases, the price of rice will decrease and vice versa if rice production decreases, the price of rice will increase. However, all of this is inversely proportional to the fact that when production increases, rice prices experience fluctuations caused by rice imports and government policies.

For the consumption, the response of rice prices to inc (income) in the first, second, third, fourth period fluctuates until the fifth period or at 25 years goes to the inflection point. This is due to increased income but the purchasing power of rice has not increased because it is caused by the needs and tastes of each individual.

\subsection{Forecast Error Variance Decomposition (FEVD) Analysis \\ FEVD analysis results table}

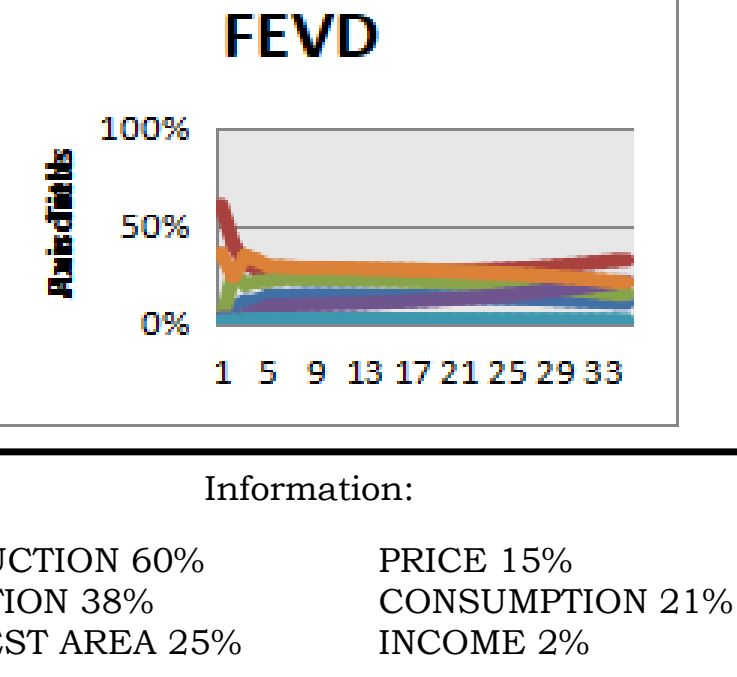

Based on the results of this analysis, the two most dominant variables in explaining rice prices in North Sumatra Province are production at $60 \%$ and inflation at $38 \%$ on condition that each variable has a $100 \%$ probability. Production is one of the variables that can affect the price of rice because production is the first place to determine the price of rice in accordance with the law of demand, if production increases, the price of rice will decrease and if production decreases, the price of rice will increase. But in reality it is inversely proportional to the existence of policies government to import rice at a much higher price. 
After production, inflation is a variable that has the second contribution to affect rice prices in North Sumatra Province. This is because if the price of rice increases continuously it will experience inflation, but in fact the price of rice in North Sumatra has fluctuated due to the price stability policy.

\section{Conclusion}

Based on the results of the discussion, it can be concluded in general, that:

1. There are 2 factors that predominantly affect rice prices in North Sumatra, namely the first $60 \%$ production because the higher the rice production, the rice price will decrease and the lower the production, the rice price will increase and the second factor is inflation of $38 \%$ in because if the price of rice continuously increases, there will be inflation, but it is different from the fact that the price of rice has fluctuated due to the stability of the price of rice.

2. Significant factors affecting rice prices in North Sumatra in the short term are inflation and in the long run there are five significant factors, namely production (prod), harvested area (field), income (inc), consumption (cons) and inflation ( inf).

3. From the Impulse Response Function analysis, it can be seen that the factors that influence the price of rice in North Sumatra can be seen from the stability, namely the production variable (Prod) reaches stability in the 25 th period, the harvest area variable (Field) reaches stability in the 28th period, the consumption variable (Cons) reaches stability in the 25th period, the income variable (Inc) reaches stability in the 20th period, the inflation variable (Inf) reaches stability in the 27 th period.

\section{Suggestions}

1. The government is advised to control rice prices, the amount of rice production and rice imports in North Sumatra by making policies to stabilize rice prices. So that people can buy rice at a stable price.

2. For future researchers, it is hoped that they can continue their research and find variables that can affect the price of rice that is more perfect

\section{References}

Ariel, 2011. Research Journal Rhemo Adiguno and Luhut Sihombing Analysis of Food Access in North Sumatra Province. USU 2012.

BPS. Central Bureau of Statistics. 2015. Indonesia in Figures 2016.

Dimas, 2014. Research Journal Dimas Brianto The Effect of Rice Production, Rice Imports, Rice Consumption Levels on Rice Prices in Indonesia. UIN Syarif Hidayatullah 2015.

Firdaus, 2014. Research Journal Rhemo Adiguno and Luhut Sihombing Analysis of Food Access in North Sumatra Province. University of North Sumatra 2012.

Hasibuan, A.S., et al. (2020). The Analysis of the Effect of Determinant Factors of Palm Oil Plantation Sector on Agricultural Sector Growth in North Sumatera. Budapest International Research and Critics Institute-Journal (BIRCI-Journal). P. 1083-1094.

Husnul, 2014. Paul Rocky Siregar Research Journal Analysis of Rice Supply in North Sumatra, University of North Sumatra 2015.

Kartika, 2011. Research Journal Dimas Brianto The Effect of Rice Production, Rice Imports, Rice Consumption Levels on Rice Prices in Indonesia. UIN Syarif Hidayatullah 2015. 
Lia, 2010. Research Journal Dimas Brianto The Effect of Rice Production, Rice Imports, Rice Consumption Levels on Rice Prices in Indonesia. UIN Syarif Hidayatullah 2015.

Lubis, N.P.S., et al. (2020). Analysis of Superior Commodities in Agricultural Sector in Some Districts of North Sumatera Province. Budapest International Research and Critics Institute-Journal (BIRCI-Journal). P. 1054-1066.

Noer and Agus, 2007. Research Journal Dimas Brianto The Effect of Rice Production, Rice Imports, Rice Consumption Levels on Rice Prices in Indonesia. UIN Syarif Hidayatullah 2015.

Pratiwi, 2011. Rhemo Adiguno and Luhut Sihombing's Plenary Research Analysis of Food Access in North Sumatra Province. University of North Sumatra 2012.

Risya, 2011. Research Journal Rhemo Adiguno and Luhut Sihombing Analysis of Food Access in North Sumatra Province. USU 2012.

Riyadi, 2012. Research Journal Dimas Brianto The Effect of Rice Production, Rice Imports, Rice Consumption Levels on Rice Prices in Indonesia. UIN Syarif Hidayatullah 2015.

Sadono Sukirno, 2015. Macro Economics. Third edition. Jakarta.

Sierdjo, 2012. Research Journal Dimas Brianto The Effect of Rice Production, Rice Imports, Rice Consumption Levels on Rice Prices in Indonesia. UIN Syarif Hidayatullah 2015.

Sugema, 2005. Research Journal Dimas Brianto The Effect of Rice Production, Rice Imports, Rice Consumption Levels on Rice Prices in Indonesia. UIN Syarif Hidayatullah 2015.

William, 2015. Paul Rocky Siregar Research Journal Analysis of Rice Supply in North Sumatra, University of North Sumatra 2015.

Zulham, 2012. Research Journal Paul Rocky Siregar Analysis of Rice Supply in North Sumatra, University of North Sumatra 2015.

Zein, 2010. Research Journal Rhemo Adiguno and Luhut Sihombing Analysis of Food Access in North Sumatra Province. USU 2012. 